\title{
Magnetic sorption materials for recovery of organic anions from aqueous solutions
}

\author{
Yuliya Petrova $^{1-}$, Ekaterina Sevast'yanova ${ }^{1}$, and Yuliya Mateyshina ${ }^{2,3}$ \\ ${ }^{1}$ Surgut State University, Editorial Department, 628412 Surgut Lenin ave. 1, Russia \\ ${ }^{2}$ Institute of Solid State Chemistry and Mechanochemistry SB RAS, 630090 Novosibirsk Kutateladze \\ str. 18, Russia
}

${ }^{2}$ Novosibirsk State Technical University, 630073 Novosibirsk Karl Marx Ave. 20, Russia

\begin{abstract}
Layered double hydroxides (LDHs) belong to the class of twodimensional anionic clays with a layered structure similar to brucite. The combination of sorption and magnetic properties of layered materials is promising. In this work, magnetic materials based on LDHs (MLDHs) were synthesized and their sorption and magnetic properties were studied. The synthesis of LDHs was carried out by a co-precipitation method followed by calcination. Intercalated $\mathrm{Mg}, \mathrm{Fe}(\mathrm{III})-, \mathrm{Mg}, \mathrm{Fe}(\mathrm{III}), \mathrm{Al}-$ and $\mathrm{Mg}, \mathrm{Al}$-LDHs were prepared using LDHs by rehydration in solutions of iron(III) citrate (Cit) or oxalate $(O x)$ followed by the calcination at $400^{\circ} \mathrm{C}$ for 2-4 h. LDHs and their thermal decomposition products were characterized by FTIR spectroscopy, laser and X-ray diffraction and thermogravimetry. The sorption experiment was carried out under static conditions using glutamic acid (Glu) as a model organic compound. The maximum sorption capacity of $\mathrm{Mg}, \mathrm{Fe}(\mathrm{III})-\mathrm{LDH}$ and $\mathrm{Mg}, \mathrm{Al}-\mathrm{FeC}$ it-LDH calcined at $400^{\circ} \mathrm{C}$ was 6.6 and $8.8 \mathrm{mg} / \mathrm{g}$ Glu, respectively. The sorption kinetics of intercalated and calcined $\mathrm{Mg}, \mathrm{Al}-$ and $\mathrm{Mg}, \mathrm{Fe}(\mathrm{III}), \mathrm{Al}-\mathrm{LDH}$ and calcined at $500^{\circ} \mathrm{C} \mathrm{Mg}, \mathrm{Fe}(\mathrm{III})-\mathrm{LDH}$ was described by the pseudo-second order model. The magnetic properties of the LDHs and thermal decomposition products were retained after the adsorption of glutamic acid, making it possible to easily separate these MLDHs from the solution by magnetic field.
\end{abstract}

\section{Introduction}

Layered double hydroxides (LDHs) showed good performance in the field of efficient adsorbent research. LDHs belong to the group of two-dimensional inorganic layered nanomaterials. The positive charged layers contain two or more metal elements, and the anions between the layers can balance charge [1-3]. LDHs have a number of advantages such as compositional flexibility, excellent anion exchange capacity, and memory effect, and can be easily customized for functional hybrid materials and nanocomposites. LDHs are broad used in many fields, but the powdered form limits their application as adsorbent

— Corresponding author: petrova_juju@surgu.ru 
in water purification [4]. Therefore, the researchers combined $\mathrm{Fe}_{3} \mathrm{O}_{4}$ as a magnetic medium with LDHs to make magnetic composite materials. In terms of recycling, magnetic LDH nanocomposites (MLDH) as the adsorbents are more conducive to separation and recovery than traditional LDHs, thereby shortening the water treatment cycle and improving overall efficiency. The MLDHs have attractive broad prospects in water treatment.

Recently new approach for synthesis of MLDH composite was developed. It based on co-precipitation method using a $\mathrm{Fe}_{3} \mathrm{O}_{4}$ suspension followed drying at $60{ }^{\circ} \mathrm{C}$ [4] or calcination at $500^{\circ} \mathrm{C}$ [5]. As it was shown by SEM and TEM images core-shell $\mathrm{Fe}_{3} \mathrm{O}_{4} @$ LDHs nanoparticles could be obtained by this approach. Jung et al. [5] synthesized magnetic core-shell $\mathrm{Fe}_{3} \mathrm{O}_{4} @ \mathrm{Mg}_{x} \mathrm{Al}-\mathrm{LDH}(x=2,3$ and 4$)$ composites by co-precipitation method (using the magnetite $\mathrm{Fe}_{3} \mathrm{O}_{4}$ microspheres synthesized by a solvothermal method), among which the calcined $\mathrm{Fe}_{3} \mathrm{O}_{4} @ \mathrm{Mg}_{4} \mathrm{Al}-\mathrm{LDH}$ has the best adsorption capacity for iodide. The maximum iodide adsorption capacity was $105.04 \mathrm{mg} / \mathrm{g}$ due to its wide interlayer spacing and largest BET surface area [5]. The recyclability test of $\mathrm{Fe}_{3} \mathrm{O}_{4} @$ LDH showed that the removal performance for iodide is maintained at $>80 \%$ even during the first to the fourth cycles. The adsorption capacity maximum of MLDH for removal of a phytohormone indole-3-butyric acid (IBA) was $522.6 \mathrm{mg} / \mathrm{g}$ [4]. Kinetics and adsorption isotherm followed the pseudo-second-order and Liu isotherm model respectively. The adsorbed sample can be easily magnetically separated and regenerated with $\mathrm{NaNO}_{3}$. The adsorption process was spontaneous and exothermic, including two path stages: surface adsorption of lamellar and interlayer anion exchange. Zhao et al. [6] prepared a magnetic ZnAl-LDH composite material, which has good adsorption energy for $\mathrm{Cr}(\mathrm{VI})$ in water due to its electrostatic attraction. Li et al. [7] synthesized a core/shell/shell Mg,Al-LDH composite material with improved magnetic separation performance for the separation and removal of pollutants such as phosphate and fluoride in water. Behbahani et al. [8] prepared Mg,Al-LDH supported on $\mathrm{Fe}_{3} \mathrm{O}_{4}-\mathrm{SiO}_{2}$ stabilized and modified with $\mathrm{CoS}-\mathrm{FeS}$ chalcogenide to determine trace disulfide blue in aqueous solution and the content of bromocresol green anionic dye. The development of MLDHs for environmental applications still need fundamental investigations to understand the mechanisms of adsorption. Despite a number of advantages of the core-shell $\mathrm{Fe}_{3} \mathrm{O}_{4} @ \mathrm{LDH}$ approach, it also has disadvantages, such as the timeconsuming process required to synthetize $\mathrm{Fe}_{3} \mathrm{O}_{4}$, prepare the suspension and age $\mathrm{Fe}_{3} \mathrm{O}_{4} @ \mathrm{LDH}$ composite with heating for $24 \mathrm{~h}$, as well as $\mathrm{Fe}_{3} \mathrm{O}_{4}$ particle size heterogeneity and substitution by competing ions in the adsorption process.

In this work, we used another approach for the preparation of oxide nanostructured materials [9]. The proposed method was based on chemical modification of anionsubstituted LDHs. It combined the simplicity of chemical methods and the possibility to prepare nanostructures directly in the matrix. During chemical reactions of anions in the interlayer space of LDHs, the reaction zone was spatially constrained by the hydroxide layers, giving rise to the conditions similar to those in 2D nanoreactors, such as LangmuirBlodgett films and self-assembling monolayers. It was found that chemical modification of intercalated LDHs results in the formation of iron oxide nanoparticles with different morphology and composition, depending on the composition of initial precursors and conditions of chemical modifications.

In this work magnetic composite materials based on $\mathrm{Mg}, \mathrm{Fe}(\mathrm{III})-, \mathrm{Mg}, \mathrm{Fe}(\mathrm{III}), \mathrm{Al}-$ and $\mathrm{Mg}, \mathrm{Al}-\mathrm{LDH}$ were synthesized by co-precipitation method followed by calcination at 400 , 500 and $600{ }^{\circ} \mathrm{C}$ for 2-4 h. Intercalated $\mathrm{Mg}, \mathrm{Fe}(\mathrm{III})-, \mathrm{Mg}, \mathrm{Fe}(\mathrm{III}), \mathrm{Al}-$ and $\mathrm{Mg}, \mathrm{Al}-\mathrm{LDH}$ were prepared using obtained LDH by rehydration in solutions of iron(III) citrate (Cit) or oxalate $(O x)$ followed the calcination at $400^{\circ} \mathrm{C}$ for $2-4 \mathrm{~h}$. LDHs and their thermal decomposition products were characterized by FTIR spectroscopy, laser and X-ray diffraction, and thermogravimetric analysis, and their adsorption and magnetic properties also were studied. Glutamic acid (Glu) was used as a model organic compound for glutamate anion adsorption 
study by MLDHs. The results were useful to evaluate the ability of MLDHs in adsorption process of organic compounds and preparing of magnetic composite materials.

\section{Material and method}

\subsection{Preparation of MLDHs}

L-Glutamic acid (> 98.5 wt.\%) and ammonium iron(III) citrate were purchased from AppliChem ITW Reagents and Sigma-Aldrich Inc. respectively. $\mathrm{MgCl}_{2} \cdot 6 \mathrm{H}_{2} \mathrm{O}, \mathrm{AlCl}_{3}$. $6 \mathrm{H}_{2} \mathrm{O}, \mathrm{FeCl}_{3} \bullet 6 \mathrm{H}_{2} \mathrm{O}, \mathrm{NaOH}, \mathrm{Na}_{2} \mathrm{CO}_{3}, \mathrm{NH}_{3} \cdot \mathrm{H}_{2} \mathrm{O}, \mathrm{K}_{2} \mathrm{C}_{2} \mathrm{O}_{4} \cdot \mathrm{H}_{2} \mathrm{O}$ ( $\geq 98.5 \%$ ), ethanol (96\%, rectified), iso-propanol (50\%) and other reagents were of analytical grade.

The Mg,Al-LDH in carbonate form was synthesized by the co-precipitation method in an alkaline solution described elsewhere [10]. Magnesium and aluminum or/and iron(III) hydroxides were co-precipitated by mixture of $\mathrm{NaOH}$ and $\mathrm{Na}_{2} \mathrm{CO}_{3}$ from chlorides under controlled $\mathrm{pH}$ 9 \pm 0.5 [11]. Samples with $\mathrm{Mg}$ :Al ratio 2:1, $\mathrm{Mg}: \mathrm{Fe}(\mathrm{III}) \quad 2: 1$ and 4:1, $\mathrm{Mg}: \mathrm{Fe}(\mathrm{III}): \mathrm{Al}$ 4:1:1 were synthesized. $\mathrm{Mg}$,Al- and $\mathrm{Mg}, \mathrm{Fe}(\mathrm{III}), \mathrm{Al}-\mathrm{LDH}$ were calcined at $400^{\circ} \mathrm{C}$ for $2 \mathrm{~h}$ (Mg,Al-400 and $\mathrm{Mg}, \mathrm{Fe}(\mathrm{III}), \mathrm{Al}-400$ layered double oxide samples) and $\mathrm{Mg}, \mathrm{Fe}(\mathrm{III})-\mathrm{LDH}$ were calcined at 400,500 and $600^{\circ} \mathrm{C}$ for $4 \mathrm{~h}\left(\mathrm{Mg}_{x} \mathrm{Fe}-400, \mathrm{Mg}_{x} \mathrm{Fe}-500\right.$ and $\mathrm{Mg}_{x} \mathrm{Fe}-600$ layered double oxide samples, $x-2$, 4) to remove $\mathrm{H}_{2} \mathrm{O}$ and $\mathrm{CO}_{2}$.

The anion exchange was performed using the Chibwe's procedure [12]. Obtained $\mathrm{Mg}, \mathrm{Al}-400$ and $\mathrm{Mg}, \mathrm{Fe}(\mathrm{III}), \mathrm{Al}-400$ layered double oxide samples were exposed to water solution containing $0.1 \mathrm{~mol} / \mathrm{L}$ of iron(III) citrate $(\mathrm{Cit})$ or oxalate $(\mathrm{Ox})$ complex under stirring and heating at $55-60^{\circ} \mathrm{C}$ for $4 \mathrm{~h}$. As a result intercalated $\mathrm{Mg}, \mathrm{Al}-\mathrm{Fe} O x-, \mathrm{Mg}, \mathrm{Al}-\mathrm{FeCit}-$, $\mathrm{Mg}, \mathrm{Fe}(\mathrm{III})-\mathrm{FeC}$ it- and $\mathrm{Mg}, \mathrm{Fe}(\mathrm{III}), \mathrm{Al}-\mathrm{Fe} O x$-LDH were synthesized by rehydration method due to memory effect of the layered double oxides. MLDHs were prepared using intercalated $\mathrm{Mg}, \mathrm{Al}-$ and $\mathrm{Mg}, \mathrm{Fe}(\mathrm{III}), \mathrm{Al}-\mathrm{LDH}$ by their calcination at $400^{\circ} \mathrm{C}$ for $2-4 \mathrm{~h}(\mathrm{Mg}, \mathrm{Al}-$ $\mathrm{Fe} O x-400, \mathrm{Mg}, \mathrm{Al}-\mathrm{FeC} i t-400$ and $\mathrm{Mg}$,Fe(III),Al-Fe $O x-400$ samples).

\subsection{Characterization}

The MLDHs, LDHs and their thermal decomposition products were structurally characterized using powder X-ray diffraction (XRD) on a diffractometer with $\mathrm{CuK}_{\alpha}$ radiation (Dron-3, Bourevestnik, JSC) and Spectrum 100 Series, Fourier transform infrared (FTIR) spectrometer (Perkin Elmer). Differential scanning calorimetry (DSC) and thermogravimetric analysis (TGA) were carried out using TGA/DSC 3+ Star System (Mettler Toledo) set-up to determine mass changes and heat effects during pyrolysis and oxidation of the samples. Particle size distribution analysis was performed using SALD2300 instrument (Shimadzu). The Glu concentrations were measured by UV spectrophotometry (UV-2600, Shimadzu).

\subsection{Adsorption experiments}

Weighed MLDHs or their thermal decomposition products samples $(50 \mathrm{mg})$ were dispersed in $50 \mathrm{~mL}$ of $10 \mathrm{mg} / \mathrm{L}$ Glu. Under stirring at a room temperature, aliquots $(3-5 \mathrm{~mL})$ of the dispersion solution were removed at different times. Then the Glu contents remaining in solution were determined by spectrophotometry using ninhydrin reaction [13] and monitoring the absorbance at $563 \mathrm{~nm}$. The amount of the adsorbed Glu by MLDH at time $t$ (adsorption capacity $q_{\mathrm{t}}, \mathrm{mg} / \mathrm{g}$ ) and the removal rate of Glu (recovery, \%) were calculated using determined concentrations of Glu in solution during adsorption experiment. 


\section{Results and discussion}

\subsection{Characterization of MLDHs and thermal decomposition products}

The FTIR spectra in ATR mode of the calcined Mg,Al-, Mg,Fe(III)- and Mg,Fe(III),AlLDHs did not contain $\mathrm{OH}$ stretching $\left(3500-3300 \mathrm{~cm}^{-1}\right)$ bands and also $\mathrm{O}-\mathrm{C}=\mathrm{O}$ asymmetric stretching (1353 $\mathrm{cm}^{-1}$ ) band of carbonate ions (Fig.1). COO- and C-O stretching (1200-1800 $\left.\mathrm{cm}^{-1}\right)$ and deformation (500-800 $\left.\mathrm{cm}^{-1}\right)$ bands, and weak C-H deformation (1350-1450 $\left.\mathrm{cm}^{-1}\right)$ bands of iron(III) citrate or oxalate complex were observed in FTIR spectra of intercalated $\mathrm{Mg}, \mathrm{Al}-\mathrm{Fe} O x$-, $\mathrm{Mg}, \mathrm{Al}-\mathrm{Fe} C i t-, \mathrm{Mg}, \mathrm{Fe}(\mathrm{III})-\mathrm{Fe} C i t-$ and $\mathrm{Mg}, \mathrm{Fe}(\mathrm{III}), \mathrm{Al}-\mathrm{Fe} O x$-LDHs (Fig. 1).

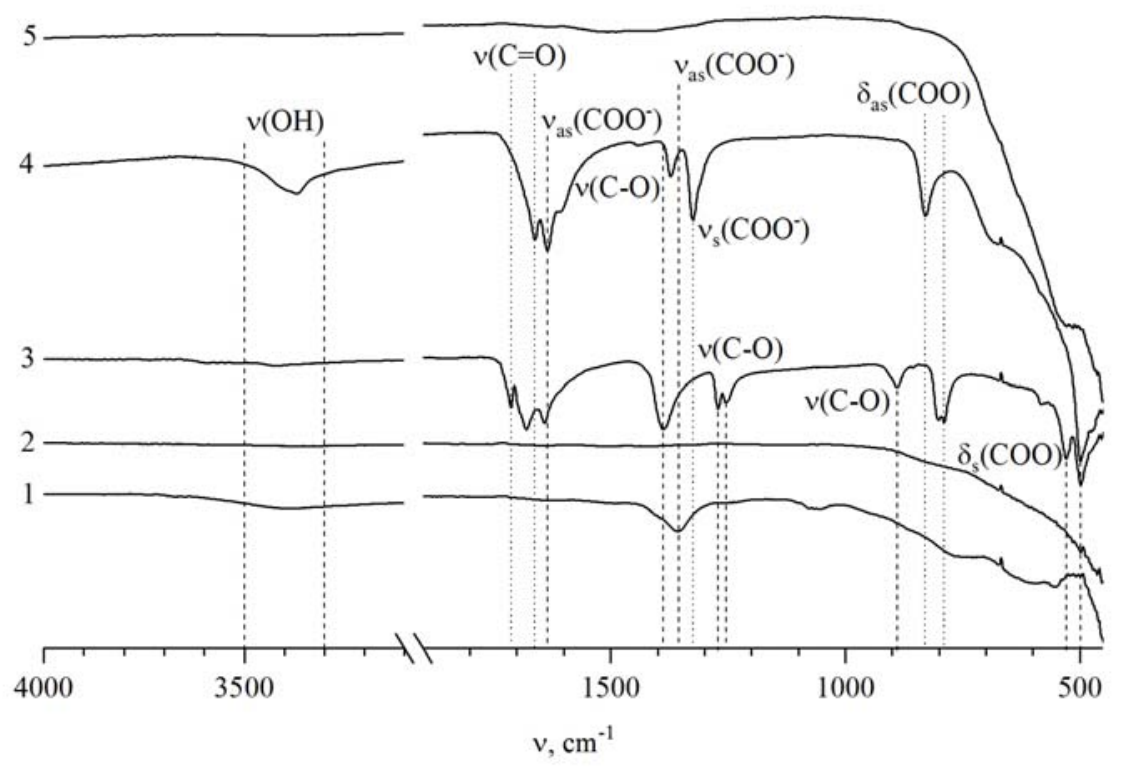

Fig. 1. FTIR: $1-\mathrm{Mg}$,Fe(III), Al-LDH; $2-\mathrm{Mg}, \mathrm{Fe}(\mathrm{III}), \mathrm{Al}-400 ; 3-\mathrm{K}_{3}\left[\mathrm{Fe}\left(\mathrm{C}_{2} \mathrm{O}_{4}\right)_{3}\right] ; 4-\mathrm{Mg}, \mathrm{Fe}(\mathrm{III}), \mathrm{Al}-$ $\mathrm{Fe} O x$-LDH; 5 - Mg,Fe(III),Al-Fe $O x-400$.

The decrease of the average particle diameter of $\mathrm{Mg}, \mathrm{Al}-$ and $\mathrm{Mg}, \mathrm{Fe}-\mathrm{LDHs}$ after calcination from 35 to $30 \mu \mathrm{m}$ and from 8 to $3 \mu \mathrm{m}$ respectively can be explained by the destruction of the layered structure, followed by cracking of crystals, and the change in the electric charge density on the surface of the particles. Subsequent rehydration of the calcined Mg,Al-LDH using an aqueous solution of iron (III) citrate complex leads to further solid phase dispersion and a decrease of the average particle diameter of $\mathrm{Mg}, \mathrm{Al}-\mathrm{FeCit}$-LDH to $9 \mu \mathrm{m}$ (Table 1). However, the rehydration of $\mathrm{Mg}$, Fe(III)-LDH leads to an increase in the average particle size up to $15 \mu \mathrm{m}$ and the disappearance of a large fraction of $\mathrm{Mg}, \mathrm{Fe}$ (III)$\mathrm{FeCit}$-LDH. Apparently, there is aggregation of the small particles through electrostatic interaction of anionic complexes like $\left.\left[\mathrm{Fe}_{2} \mathrm{C}_{6} \mathrm{H}_{4} \mathrm{O}_{7}\right]_{2}\left(\mathrm{H}_{2} \mathrm{O}\right)_{2}\right]^{2-}$ with charged surface of LDH. It has been shown also, that particle size of $\mathrm{Mg}, \mathrm{Fe}(\mathrm{III}), \mathrm{Al}-\mathrm{Fe} O x-\mathrm{LDH}$ after calcination drastically reduces. As we believe this may be due to the destruction of the layered structure and the formation of $\mathrm{Fe}_{3} \mathrm{O}_{4}$ nanoparticles. 
Table 1. Particle size of LDHs and thermal decomposition products by the laser diffraction method.

\begin{tabular}{|c|c|c|c|}
\hline Sample & $\begin{array}{c}\text { Average } \\
\text { particle } \\
\text { diameter }(\boldsymbol{\mu m})\end{array}$ & $\begin{array}{c}\text { Median } \\
\text { diameter } \\
(\boldsymbol{\mu m})\end{array}$ & $\begin{array}{c}\text { Modal } \\
\text { diameter } \\
(\boldsymbol{\mu m})\end{array}$ \\
\hline $\mathrm{Mg}, \mathrm{Al}-\mathrm{LDH}$ & 36.0 & 43.8 & 49.3 \\
\hline $\mathrm{Mg}, \mathrm{Al}-400$ & 30.2 & 39.1 & 79.3 \\
\hline $\mathrm{Mg}, \mathrm{Al}-\mathrm{Fe} C i t-\mathrm{LDH}$ & 9.2 & 11.0 & 19.0 \\
\hline $\mathrm{Mg}, \mathrm{Al}-\mathrm{Fe} O x$-LDH & 17.4 & 18.5 & 19.0 \\
\hline $\mathrm{Mg}, \mathrm{Al}-\mathrm{Fe} O x-400$ & 1.2 & 0.3 & 0.1 \\
\hline $\mathrm{Mg}, \mathrm{Fe}(\mathrm{III})-\mathrm{LDH}{ }^{*}$ & 8.2 & 9.8 & 19.0 \\
\hline $\mathrm{Mg}, \mathrm{Fe}(\mathrm{III})-400^{*}$ & 2.7 & 2.6 & $0.2 ; 19.3$ \\
\hline $\mathrm{Mg}, \mathrm{Fe}-500^{*}$ & 3.2 & 3.4 & 5.8 \\
\hline $\mathrm{Mg}, \mathrm{Fe}-600 *$ & 4.4 & 18.6 & 19.0 \\
\hline $\mathrm{Mg}, \mathrm{Fe}(\mathrm{III})-\mathrm{Fe} C i t-\mathrm{LDH}$ & 15.1 & 41.5 & 79.3 \\
\hline $\mathrm{Mg}, \mathrm{Fe}(\mathrm{III}), \mathrm{Al}-\mathrm{LDH}$ & 18.1 & 30.2 & 49.3 \\
\hline $\mathrm{Mg}, \mathrm{Fe}(\mathrm{III}), \mathrm{Al}-400$ & 17.1 & 13.8 & 7.3 \\
\hline $\mathrm{Mg}, \mathrm{Fe}(\mathrm{III}), \mathrm{Al}-\mathrm{Fe} O x$-LDH & 12.5 & 0.6 & 0.1 \\
\hline $\mathrm{Mg}, \mathrm{Fe}(\mathrm{III}), \mathrm{Al}-\mathrm{Fe} O x-400$ & 1.9 & & 5.7 \\
\hline
\end{tabular}

${ }^{*} \mathrm{Mg}: \mathrm{Fe}(\mathrm{III})$ ratio 2:1

X-ray diffraction analysis $\left(\mathrm{CuK}_{\alpha}, \lambda 1.5418 \AA, 2 \theta\right.$ scanning step $\left.0.01^{\circ}\right)$ showed the complete destruction of the layered structure of $\mathrm{Mg}, \mathrm{Fe}(\mathrm{III})-\mathrm{LDH}$ calcined at 500 and $600{ }^{\circ} \mathrm{C}$ and the formation of mixed oxides with the structure of magnetite, spinel and periclase. The characteristic sharp (003), (006) and (012) peaks of Mg,Al-LDH have decreased and widened in XRD pattern of Mg,Al-400 (Fig. 2). This indicates the partial destruction of the metal-hydroxide structure and the formation of amorphous metastable mixed oxides after calcination of $\mathrm{Mg}, \mathrm{Al}-\mathrm{LDH}$ at $400{ }^{\circ} \mathrm{C}$. X-ray amorphous products containing $\mathrm{Fe}_{3} \mathrm{O}_{4}$ magnetite phase (JCPDS 65-3107) are formed after calcination of intercalated at $400^{\circ} \mathrm{C} \mathrm{Mg}, \mathrm{Al}-\mathrm{Fe} O x-, \mathrm{Mg}, \mathrm{Al}-\mathrm{FeC}$ it-, $\mathrm{Mg}$,Fe(III)-FeCit- and $\mathrm{Mg}$,Fe(III),Al$\mathrm{Fe} O x$-LDH (Fig. 2). The basal spacing, obtained from (220), (311), (400), (433), (511) and (440) diffraction peaks, indicated in XRD pattern of partially decomposed $\mathrm{Mg}$, AlFe(III)Cit-400 sample and attributed to magnetite phase (Fig. 2, pattern 3), was 2.95, 2.51, $2.10,1.69,1.60$ and $1.48 \AA$, respectively. 


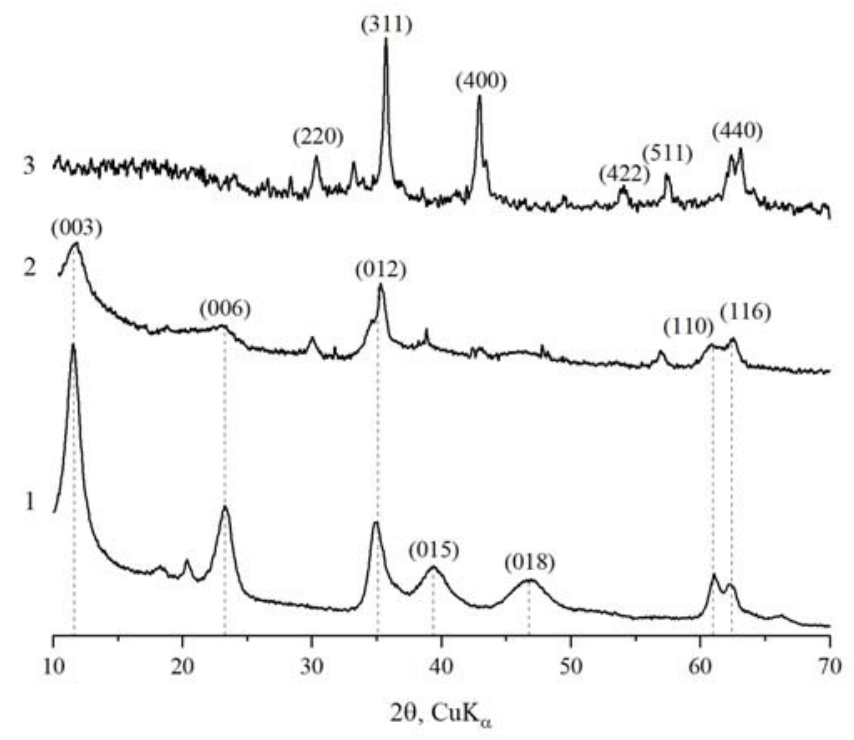

Fig. 2. XRD patterns $\left(\mathrm{CuK}_{\alpha}, \lambda 1.5418 \AA, 2 \theta\right.$ scanning step $\left.0.01^{\circ}\right)$ : 1 - Mg,Al-LDH, 2 - Mg,Al-400, 3 -

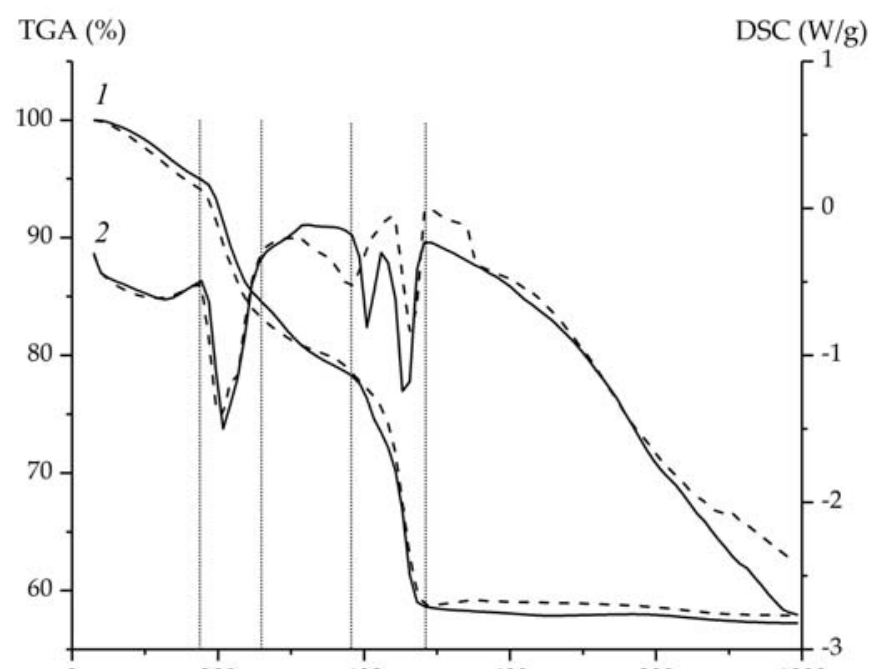

$\mathrm{Mg}, \mathrm{Al}-\mathrm{Fe} C i t-400$.

Fig. 3. TGA (1) and DSC (2) curves for Mg,Al-Fe $O x$ - (solid) and $\mathrm{Mg}$,Fe(III), Al-Fe $O x$-LDH (dashed) samples. Program: the temperature range of $20-1000^{\circ} \mathrm{C}$; heating rate $5^{\circ} \mathrm{C} / \mathrm{min}$ in the inert gas (nitrogen) with gas flow rate of $50 \mathrm{~mL} / \mathrm{min}$. 


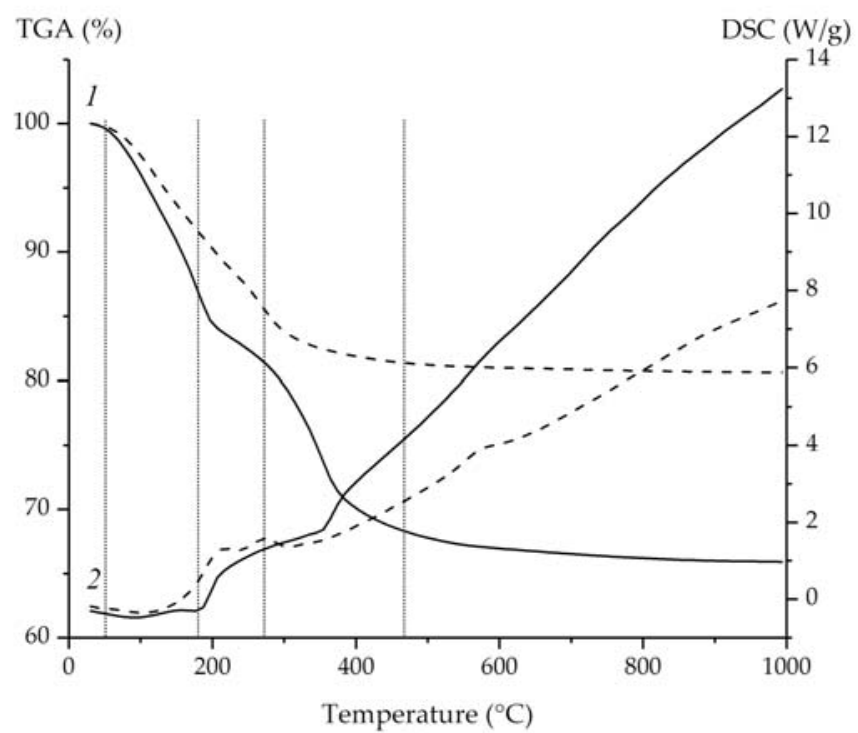

(a)

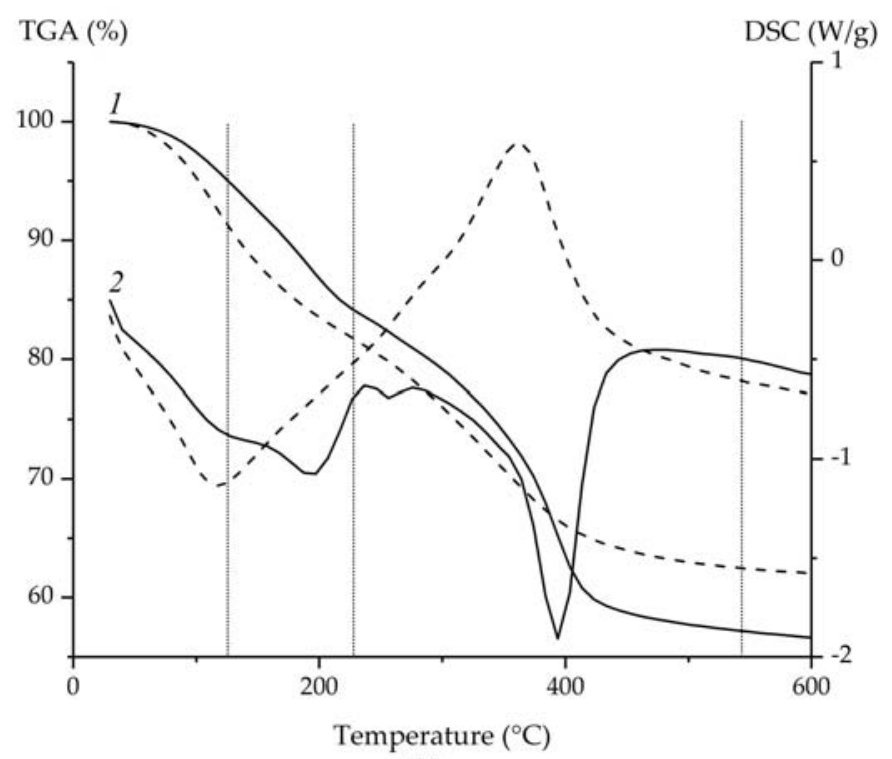

(b)

Fig. 4. TGA (1) and DSC (2) curves for: (a) Mg,Fe(III)- (solid) and Mg,Fe(III)-FeCit-LDH (dashed); (b) $\mathrm{Mg}, \mathrm{Al}$ - (solid) and Mg,Al-FeCit-LDH (dashed) samples. Program: the temperature range of 20$1000^{\circ} \mathrm{C}$; heating rate $5^{\circ} \mathrm{C} / \mathrm{min}$ in the oxidizing atmosphere (synthetic air) with gas flow rate of 50 $\mathrm{mL} / \mathrm{min}$. 
Using differential thermal analysis endothermic effects were observed at $195-250^{\circ} \mathrm{C}$ (removal of interlayer water and dehydration of metal-hydroxide layers) and $395-480^{\circ} \mathrm{C}$ (decomposition of the brucite-like layer and oxalate complex, as well as loss of interlayer carbonate ions) in DSC curves (inert gas) of the intercalated $\mathrm{Mg}$, $\mathrm{Al}-$ and $\mathrm{Mg}$, $\mathrm{Fe}$ (III), AlLDHs (Fig. 3). During the thermal decomposition of $\mathrm{Mg}$,Fe(III)-LDH (oxidizing atmosphere), three mass loss steps have been observed in TGA curves: the low-temperature region $\left(50-180^{\circ} \mathrm{C}\right)$ corresponds to the removal of interlayer and adsorbed water, region at $180-275^{\circ} \mathrm{C}$ is attributed to the removal of interlayer water, and the high-temperature region $\left(275-465^{\circ} \mathrm{C}\right)$ corresponds to the decomposition of metal hydroxide layers and interlayer carbonate anions (Fig. 4a). In the range from 30 to $600^{\circ} \mathrm{C}$ the total mass loss for $\mathrm{Mg}, \mathrm{Fe}(\mathrm{III})-\mathrm{LDH}$ was $33.1 \%$ and for $\mathrm{Mg}$,Fe(III)-FeCit-LDH was $18.0 \%$. In TGA and DSC curves of the oxidative thermolysis of Mg,Al-FeCit-LDH (Fig. 4b) in the range of 50$220^{\circ} \mathrm{C}\left(18 \%\right.$ mass loss) dehydration processes were observed (endothermic peak at $125^{\circ} \mathrm{C}$ ), and in a wide range of $220-535^{\circ} \mathrm{C}(20 \%$ mass loss $)$ the processes could be attributed to decarboxylation and oxidative destruction of citrate anion (exothermic peak $335^{\circ} \mathrm{C}$ ).

The magnetic permeability of calcined LDH Mg,Fe(III)-500, Mg,Fe(III)-600, Mg,Al$\mathrm{Fe} O x-400$ and $\mathrm{Mg}, \mathrm{Fe}(\mathrm{III}), \mathrm{Al}-\mathrm{Fe} O x-400$ is positive and greater than for typical ferromagnets. Magnetic properties in an external strong magnetic field are most noticeable for $\mathrm{Mg}$, $\mathrm{Fe}(\mathrm{III})-$ 600 and $\mathrm{Mg}, \mathrm{Fe}(\mathrm{III}), \mathrm{Al}-\mathrm{Fe} O x-400$ sample. It should be noted that $\mathrm{Mg}, \mathrm{Fe}(\mathrm{III})-, \mathrm{Mg}, \mathrm{Al}-$, $\mathrm{Mg}, \mathrm{Al}-\mathrm{Fe} O x, \mathrm{Mg}, \mathrm{Fe}(\mathrm{III}), \mathrm{Al}-$ and $\mathrm{Mg}, \mathrm{Fe}(\mathrm{III}), \mathrm{Al}-\mathrm{Fe} O x$-LDH samples and calcined $\mathrm{Mg}, \mathrm{Fe}(\mathrm{III})-400$ samples do not exhibit magnetic properties. This confirms the destruction of the layered structure and the formation of magnetite, which is responsible for the magnetic properties.

\subsection{Adsorption properties and kinetics}

The sorption experiment using MLDH and thermal decomposition products was carried out under static conditions with initial solution $10 \mathrm{mg} / \mathrm{L}$ glutamic acid at room temperature. The kinetics for removal of Glu was studied and two commonly used models were applied to fitting the experiment results: 1) Lagergren's first-order kinetic model and 2) Ho's pseudo second-order [14]. The maximum equilibrium sorption capacity $\left(q_{\mathrm{e}}\right)$ was 6.6 and 8.8 $\mathrm{mg} / \mathrm{g}$ (recovery 76 and 88\%) for $\mathrm{Mg}, \mathrm{Fe}(\mathrm{III})-400$ and $\mathrm{Mg}$,Al-FeCit-400 with $\mathrm{Mg}: \mathrm{Fe}(\mathrm{III})$ ratio $4: 1$ and 2:1 respectively, that could be explained by rehydration and partial restoration of the layered structure in solution (Table 2). It have been shown on the example of $\mathrm{Mg}$, AlLDH that sorption capacity depends on intercalated anion in iron(III) complex: sorption capacity of $\mathrm{Mg}, \mathrm{Al}-\mathrm{FeCit}-400$ has increased 2.7 times compared to $\mathrm{Mg}, \mathrm{Al}-\mathrm{Fe} O x-400$. The sorption capacity of $\mathrm{Mg}, \mathrm{Fe}(\mathrm{III})-\mathrm{LDH}$ samples calcined at $500^{\circ} \mathrm{C}$ decreases compared to those calcined at $400^{\circ} \mathrm{C}$. The sorption capacity of $\mathrm{Mg}, \mathrm{Al}, \mathrm{Fe}(\mathrm{III})-\mathrm{Fe}(\mathrm{III}) \mathrm{Ox}-400$ and $\mathrm{Mg}, \mathrm{Al}-$ $\mathrm{Fe}(\mathrm{III}) O x-400$ is 3.8 and $3.2 \mathrm{mg} / \mathrm{L}$ respectively.

The pseudo second-order kinetic model fits the experimental data better, indicating that the rate-limiting step is a chemical adsorption process between Glu and the intercalated $\mathrm{Mg}, \mathrm{Al}-$ and $\mathrm{Mg}, \mathrm{Fe}(\mathrm{III}), \mathrm{Al}-\mathrm{LDH}$ calcined at $400^{\circ} \mathrm{C}$ (Mg,Al-Fe $\mathrm{Ox}-400$ and $\mathrm{Mg}, \mathrm{Fe}$ (III), Al$\mathrm{FeO} x-400$ ) and the calcined at $500^{\circ} \mathrm{C} \mathrm{Mg}_{4} \mathrm{Fe}(\mathrm{III})-500$ (Table 2). Meanwhile, the first-order and the second-order models fit well the experimental data of Glu adsorption process by the calcined $\mathrm{Mg}, \mathrm{Fe}(\mathrm{III})-400$, and only the first-order model fits for Glu adsorption by $\mathrm{Mg}$,AlFeCit-400. Probably the sorption kinetics of intercalated and calcined samples depends on LDH:magnetite ratio in the obtained MLDH.

The magnetic properties of intercalated $\mathrm{Mg}, \mathrm{Al}-\mathrm{Fe} O x$ and $\mathrm{Mg}, \mathrm{Fe}(\mathrm{III}), \mathrm{Al}-\mathrm{Fe} O x$-LDH, calcined at $400^{\circ} \mathrm{C}$, and $\mathrm{Mg}, \mathrm{Fe}(\mathrm{III})-\mathrm{LDH}$, calcined at $500-600^{\circ} \mathrm{C}$, were preserved after glutamic acid adsorption, which could make it easy to separate them from solutions in magnetic field. 
Table 2. Kinetic parameters for adsorption experiments.

\begin{tabular}{|c|c|c|c|c|c|c|c|}
\hline \multirow[b]{2}{*}{ Sample } & \multirow{2}{*}{$\begin{array}{c}q_{\mathrm{e}} \\
\mathrm{mg} / \mathrm{g}\end{array}$} & \multicolumn{3}{|c|}{ Pseudo first-order } & \multicolumn{3}{|c|}{ Pseudo second-order } \\
\hline & & $\begin{array}{c}q_{\mathrm{e}}, \\
\mathrm{mg} / \mathrm{g}\end{array}$ & $k_{1, \min ^{-1}}$ & $\mathbf{R}^{2}$ & $\begin{array}{c}q_{\mathrm{e}} \\
\mathrm{mg} / \mathrm{g}\end{array}$ & $\begin{array}{c}k_{2}, \\
\mathrm{~g} \cdot(\mathrm{g} \cdot \mathrm{min})^{-1}\end{array}$ & $\mathbf{R}^{2}$ \\
\hline $\mathrm{Mg}_{4} \mathrm{Fe}-400$ & 6.65 & 6.91 & $8.8 \cdot 10^{-3}$ & 0.9886 & 9.25 & 0.73 & 0.9874 \\
\hline $\mathrm{Mg}_{4} \mathrm{Fe}-500$ & 1.52 & - & - & - & 1.94 & 5.52 & 0.9407 \\
\hline $\mathrm{Mg}_{2} \mathrm{Fe}-400$ & 1.51 & 1.64 & $3.4 \cdot 10^{-3}$ & 0.9034 & 1.48 & 9.89 & 0.9312 \\
\hline $\mathrm{Mg}_{3} \mathrm{Fe}-500^{*}$ & 49.28 & 54.63 & $1.3 \cdot 10^{-4}$ & 0.9945 & 51.35 & 0.19 & 0.9963 \\
\hline $\mathrm{Mg}, \mathrm{Al}-\mathrm{Fe} O x-400$ & 3.20 & 6.90 & $7.1 \cdot 10^{-3}$ & 0.7132 & 3.55 & 3.70 & 0.9189 \\
\hline $\mathrm{Mg}, \mathrm{Al}-\mathrm{Fe} C i t-400$ & 8.77 & 9.80 & $6.7 \cdot 10^{-3}$ & 0.9659 & - & - & - \\
\hline $\begin{array}{c}\mathrm{Mg}, \mathrm{Fe}(\mathrm{III}), \mathrm{Al}- \\
\mathrm{Fe} O x-400\end{array}$ & 3.85 & - & - & - & 3.67 & 21.26 & 0.9556 \\
\hline
\end{tabular}

[11]

\section{Conclusion}

The present study investigated the sorption and magnetic properties of MLDHs for glutamic acid removal. The co-precipitation method followed by iron (III) complex intercalation and calcination have been used to synthesize MLDHs and thermal decomposition products.

$\mathrm{Mg}, \mathrm{Fe}(\mathrm{III})-$ and intercalated $\mathrm{Mg}, \mathrm{Al}-\mathrm{Fe} C i t-\mathrm{LDH}$ calcined at $400^{\circ} \mathrm{C}(\mathrm{MLDH})$ might be potential magnetic materials for the removal of glutamic acid from aqueous solution. It was found that glutamic acid could be removed effectively with a removal rate of $76 \%$ (Mg,Fe(III)-400) and 88\% (Mg,Al-FeCit-400). The kinetic data fit well the pseudo secondorder kinetic model with good determination coefficient for intercalated and partly thermal decomposed MLDH (Mg,Al-FeOx-400 and $\mathrm{Mg}, \mathrm{Fe}(\mathrm{III}), \mathrm{Al}-\mathrm{Fe} O x-400)$ and the calcined at $500^{\circ} \mathrm{C} \mathrm{LDH} \mathrm{(Mg,Fe(III)-500)} \mathrm{samples.}$

It was shown that the magnetic properties of obtained MLDH (intercalated Mg,Al$\mathrm{Fe} O x$ and $\mathrm{Mg}, \mathrm{Fe}(\mathrm{III}), \mathrm{Al}-\mathrm{Fe} O x$-LDH calcined at $400^{\circ} \mathrm{C}$ ) and $\mathrm{Mg}$,Fe(III)-LDH calcined at $500-600^{\circ} \mathrm{C}$ were preserved after glutamic acid adsorption. Thus they can be separated from aqueous solution due to its magnetic properties.

The authors acknowledge financial support from the Government of the KhantyMansiysk Autonomous Okrug-Yugra (order № 10-P-1308 dated 04.09.2020).

\section{References}

1. F. Khodam, Z. Rezvani, A.R. Amani-Ghadim, J. Ind. Eng. Chem. 21, 1286 (2015)

2. R.R. Shan, L.G. Yan, Y.M. Yang, K. Yang, S.J. Yu, H.Q. Yu, B.C. Zhu, B. Du, J. Ind. Eng. Chem. 21, 561 (2015)

3. L. Lu, J. Li, D.H.L. Ng, P. Yang, P. Song, M. Zuo, J. Ind. Eng. Chem. 46, 315 (2017)

4. L.X. Zhao, H. Xiao, M.H. Li, M. Xie, N. Li, R.S. Zhao, J. Hazard Mater. 408, 124446 (2021)

5. I.-K. Jung, Y. Jo, S.-C. Han, J.-I. Yun, Sci. Total Environ. 705, 135814 (2020) 
6. S. Zhao, M. Wu, R. Jing, X. Liu, Y. Shao, Q. Zhang, F. Lv, A. Liu, Z. Meng, Appl. Clay Sci. 182, 105297 (2019)

7. F. Li, J. Jin, Z. Shen, H. Ji, M. Yang, Y. Yin, J. Hazard. Mater. 388, 121734 (2020)

8. E.S. Behbahani, K. Dashtian, M. Ghaedi, Microchem. J. 152, 104431 (2020)

9. M.P. Nikiforov, M.V. Chernysheva, A.A. Eliseev, A.V. Lukashin, Yu.D. Tretyakov, Yu.V. Maksimov, I.P. Suzdalev, P. Goernert, Mater. Sci. Eng. B 109, 226 (2004)

10. S.P. Newman, W. Jones, J. Solid State Chem. 148, 26 (1999)

11. F. Jiao, L. Shuai, J. Yu, X. Jiang, X. Chen, S. Du, Trans. Nonferrous Met. Soc. China 24, 3971 (2014)

12. K. Chibwe, W. Jones, J. Chem. Soc., Chem. Commun. 14, 926 (1989)

13. S.-W. Sun, Y.-C. Lin, Y.-M. Weng, M.-J. Chen, J. Food Compos. Anal. 19, 112 (2006)

14. Z.M. Ni, S.J. Xia, L.G. Wang, F.F. Xing, G.X. Pan, J. Colloid Interface Sci., 316, 284 (2007) 